\title{
Plasticity of European flounder life history patterns discloses alternatives to catadromy
}

\author{
Françoise Daverat ${ }^{1, *, * *}$, Pedro Morais ${ }^{2,3, * *}$, Ester Dias ${ }^{3,4}$, John Babaluk $^{5}$, Jean Martin ${ }^{1}$, \\ Mélissa Eon ${ }^{1}$, Ronan Fablet ${ }^{6}$, Christophe Pécheyran ${ }^{7}$, Carlos Antunes $^{3,8,9}$ \\ ${ }^{1}$ Institut National de Recherche en Sciences et Technologies pour l'Environnement et l'Agriculture (IRSTEA), UR EPBX, \\ 50 av. de Verdun, Cestas Cedex 33612, France \\ ${ }^{2}$ International Center for Coastal Ecohydrology (ICCE), Solar do Capitão-Mor, Horta das Figuras, EN 125, Faro 8005-518, \\ Portugal \\ ${ }^{3}$ Centro Interdisciplinar de Investigação Marinha e Ambiental (CIMAR/CIIMAR), Universidade do Porto, \\ Rua dos Bragas 289, Porto 4050-123, Portugal \\ ${ }^{4}$ Instituto de Ciências Biomédicas de Abel Salazar, Universidade do Porto, Lg. Prof. Abel Salazar 2, Porto 4099-003, Portugal \\ ${ }^{5}$ Fisheries and Oceans Canada, 501 University Crescent, Winnipeg, Manitoba R3T 2N6, Canada \\ ${ }^{6}$ Centre National de la Recherche Scientifique (CNRS), FRE 3167 LabSTICC CS 83818, Technopôle Brest-Iroise 29238, France \\ ${ }^{7}$ Université de Pau et des Pays de l'Adour, UMR 5254 IPREM-LCABIE, Hélioparc Pau, 64053 Pau Cedex 09, France \\ ${ }^{8}$ Aquamuseu do Rio Minho, Parque do Castelinho s/n, Vila Nova de Cerveira 4920-290, Portugal \\ ${ }^{9}$ Escola Superior Gallaecia, Largo das Oliveiras s/n, Vila Nova de Cerveira 4920-275, Portugal
}

\begin{abstract}
European flounder Platichthys flesus life history patterns were investigated in 3 basins along a latitudinal gradient (Minho, N Portugal; Gironde, SW France; Seine, N France). We used coupled $\mathrm{Sr}: \mathrm{Ca}$ and $\mathrm{Ba}: \mathrm{Ca}$ otolith signatures and microstructure to retrospectively determine habitats occupied by flounder during their life, including early larval ontogeny. Flounder exhibited high life history plasticity among and even within basins, apparent by the diversity of habitats used during larval ontogeny and throughout their lives, and by the age at which flounder migrated to freshwater. Egg signatures probably had a strong maternal influence, and our interpretation suggests that flounder spawned and/or hatched predominantly in brackish waters in the Minho, while in the Gironde and Seine, flounder spawned and/or hatched either in coastal, brackish or freshwater environments. The freshwater egg signature was most frequent in the Seine. These interpretations contradict the current general assumption that flounder spawn exclusively in coastal waters. During pre-metamorphosis and metamorphosis, flounder were predominantly in brackish waters in the Minho, while in the Gironde and Seine, they were mainly in coastal and freshwater environments, respectively. The diversity of flounder life histories (LH) (i.e. sequence of habitat residence: freshwater, brackish or coastal) after metamorphosis was similar between the Minho $(\mathrm{LH}=13)$, Gironde $(\mathrm{LH}=13)$ and Seine $(\mathrm{LH}=14)$ basins. The age at which flounder migrated to freshwater also varied among sites, at an earlier age in the Minho and Gironde $(<0.5 \mathrm{yr}$ old $)$ than in the Seine, where flounder migrating from the coast into freshwater reached maximum frequencies at age $1.3 \mathrm{yr}$ old. Thus, catadromy in European flounder may be facultative, and the factors influencing flounder high LH plasticity deserve thorough research.
\end{abstract}

KEY WORDS: Platichthys flesus $\cdot$ Migration $\cdot$ Otolith microchemistry $\cdot$ LA-ICP-MS $\cdot \mathrm{Sr}: \mathrm{Ca} \cdot \mathrm{Ba}: \mathrm{Ca}$. Phenotypic plasticity $\cdot$ Bayesian labeling $\cdot$ Hidden Markov models

Resale or republication not permitted without written consent of the publisher

\section{INTRODUCTION}

Studies of fish life histories regarding their migratory behavior increased with the advancement of otolith microchemistry analysis (Begg et al. 2005,
Campana 2005), particularly those of diadromous fishes sensu McDowall (1997). Diadromous fishes perform regular migrations between freshwater and the sea, and often migrations occur at a predictable time or life history phase. Migrations must be medi- 
ated by physiological processes, and they involve the bulk of the population. There are 3 types of diadromous migrations: anadromy, catadromy and amphidromy. Anadromous fishes feed and grow at sea and migrate, as adults, to reproduce in freshwater, catadromous fishes feed and grow in freshwater and migrate to sea to reproduce, and amphidromous fishes migrate to sea soon after hatching, where they feed and grow, and migrate again to freshwater as postlarvae or juveniles (see McDowall 1997 for more detailed definitions). However, classifying a species as strictly anadromous, catadromous or amphidromous is not straightforward since there are species that exhibit various migratory tactics and variations of the predominant one (McDowall 1997, Arai et al. 2006, Chapman et al. 2006, Barriga et al. 2007, Mangel \& Satterthwaite 2008).

Those species capable of developing diverse life history strategies, particularly as they relate to migratory tactics, are able to persist in varied and unpredictable environments (Chapman et al. 2006, Kerr \& Secor 2012). It is also hypothesized that the coexistence of different life history strategies within 1 population might result from the success of those diverse strategies to maximize individual fitness (Arai et al. 2006). Thus, life history plasticity has obvious adaptive value at the species and population levels and even at the individual level; however, it is among the least explored topics within ichthyology. Indeed, there are only a few examples of species exhibiting this characteristic, such as inanga Galaxias maculatus (Chapman et al. 2006, Barriga et al. 2007), pond smelt Hypomesus nipponensis (Arai et al. 2006), 3-spined stickleback Gasterosteus aculeatus (Arai et al. 2003), several eel species Anguilla spp. (Tsukamoto et al. 2002, Daverat el al. 2006) and salmonids (McDowall 1997, Mangel \& Satterthwaite 2008). The mechanisms are not well understood, but differences in biotic and abiotic interactions, individual growth rates and genetics probably explain the majority of the plasticity at the species and population levels.

The European flounder Platichthys flesus (hereafter, flounder) is another species exhibiting great plasticity of several life traits, including alternative reproductive strategies. Summers (1979) established that this species is catadromous, and this is still the most widely accepted life history (Franco et al. 2008). However, there is still controversy about classifying flounder as catadromic, semi-catadromic, estuarine migrant, marine-estuarine opportunistic (Elliott et al. 2007) or even as a truly estuarine resident species (Elliott \& Dewailly 1995). Recent works clearly proved that flounder is not an estuarine resident spe- cies (Daverat et al. 2011, Morais et al. 2011), although field observations confirmed that flounder use estuarine habitats (Jager 1999, Marchand et al. 2003) as well as freshwater habitats for extended periods (Radforth 1940, Beaumont \& Mann 1984). Indeed, freshwater was found to trigger the metamorphosis of flounder (Hutchinson \& Hawkins 2004), and larvae are able to migrate upstream efficiently to their estuarine nursery ground using selective tidal transport (Bos 1999).

Flounder have very distinct reproductive strategies between Atlantic estuaries and the Baltic Sea. In the Baltic Sea, 2 alternative strategies were described: one for southern and one for northern portions of the sea (Nissling et al. 2002). In the southern Baltic, flounder migrate from coastal feeding areas to spawn in the deep basins and have large, pelagic eggs which are positively buoyant despite the low salinity of the area (Nissling et al. 2002, Nissling \& Dahlman 2010). In the northern Baltic, flounder are more stationary and spawn in shallow bank or coastal areas. The eggs of these flounder are smaller, more thickshelled and demersal and can be fertilized at lower salinities, down to 6.5 (Solemdal 1967). A recent study has shown that there are genetic differences between flounder from the northern and southern part of the Baltic, corresponding to the outlined ecological types (Florin \& Höglund 2008). Further south in the species' distribution area, in the Minho basin (NW Iberian Peninsula), it was hypothesized that flounder used both the coastal area and the estuary as spawning grounds (Morais et al. 2011). Alternative habitat use was also suggested in the Gironde estuary population (W France), where most flounder used freshwater habitat in the juvenile stage, although a smaller proportion of the sample was resident in the brackish estuary or undertook several movements between coastal, estuarine and freshwater habitats (Daverat et al. 2011).

The studies conducted in the Minho (Morais et al. 2011) and Gironde basins (Daverat et al. 2011) inferred the migration patterns and habitats used by flounder by analyzing trace elements incorporated in the sagittal otoliths of fish (Campana 1999, Gillanders 2005). Sagittal otoliths (hereafter, otoliths) are 1 of 3 pairs of otoliths that fish have in their inner ear and are composed of calcium carbonate $\left(\mathrm{CaCO}_{3}\right)$ in a non-collagenous matrix (see Campana 1999 and Elsdon et al. 2008 for a comprehensive review of otoliths and otolith microchemistry). Trace elements, such as strontium $(\mathrm{Sr})$ and barium $(\mathrm{Ba})$, are incorporated into otoliths proportionally to their concentration in the ambient water or as a function of fish 
metabolism and diet (Campana 1999), substituting calcium (Ca) in the $\mathrm{CaCO}_{3}$ otolith matrix (Elsdon \& Gillanders 2003a). The absorption pathways of elements are through branchial uptake or intestinal assimilation into the plasma and then to the crystallizing otolith (Campana 1999). Sr and Ba are particularly suitable to reconstruct environmental history and infer migration patterns of diadromous fish (Campana 2005) since the concentration of $\mathrm{Sr}$ is substantially higher in seawater than in estuaries or freshwater ecosystems (Secor \& Rooker 2000, Kraus \& Secor 2004), while the opposite trend is observed for Ba (Elsdon \& Gillanders 2006, Miller 2011). Variations of these relationships between otolith and ambient concentrations may occur as a function of fish physiology (Yamashita et al. 2000) or local geology (Kraus \& Secor 2004, Elsdon \& Gillanders 2006). The combined analysis of $\mathrm{Sr}: \mathrm{Ca}$ and $\mathrm{Ba}: \mathrm{Ca}$ ratios along the growth plane of otoliths provides a powerful discriminative tool to retrospectively track fish migration and assign environments based on salinity.

The aim of the present study was to explore the alternative habitat use tactics of flounder along a latitudinal gradient from the north of Portugal to the north of France, using an indirect, retrospective approach: otolith microchemistry analysis using laser ablation inductively coupled plasma mass spectrometry (LA-ICP-MS). The first objective was to identify the alternative use of coastal habitat or estuarine habitat as a spawning area. The second objective was to investigate the level of dependence on freshwater habitat use at the juvenile stage. A comparison of the life histories of flounder was undertaken by comparing the habitat use of flounder samples from 3 different locations: the Minho estuary and adjacent coastal area (N Portugal), the Gironde estuary (SW France) and the Seine estuary and adjacent coastal area (N France).

\section{MATERIALS AND METHODS}

\section{Study sites}

Minho estuary and adjacent coastal area

The Minho estuary and its adjacent coastal area are located on the NW Iberian Peninsula between Portugal and Spain (Fig. 1). The estuary has an area of $\sim 23 \mathrm{~km}^{2}$, with $9 \%$ of this area made up of intertidal zone. It is a mesotidal estuary, with tides varying between 0.7 and $3.7 \mathrm{~m}$ (Alves 1996), and it tends to

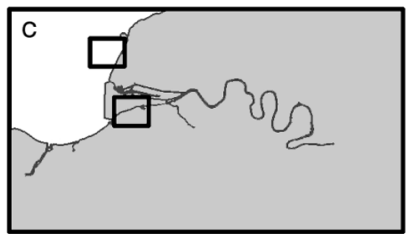

Seine estuary

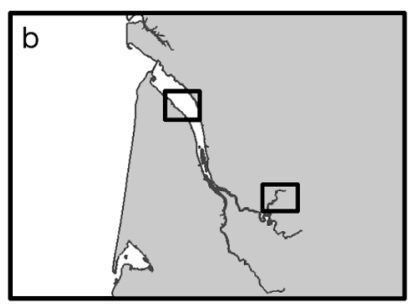

Gironde estuary

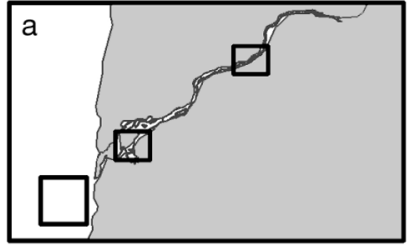

Minho estuary

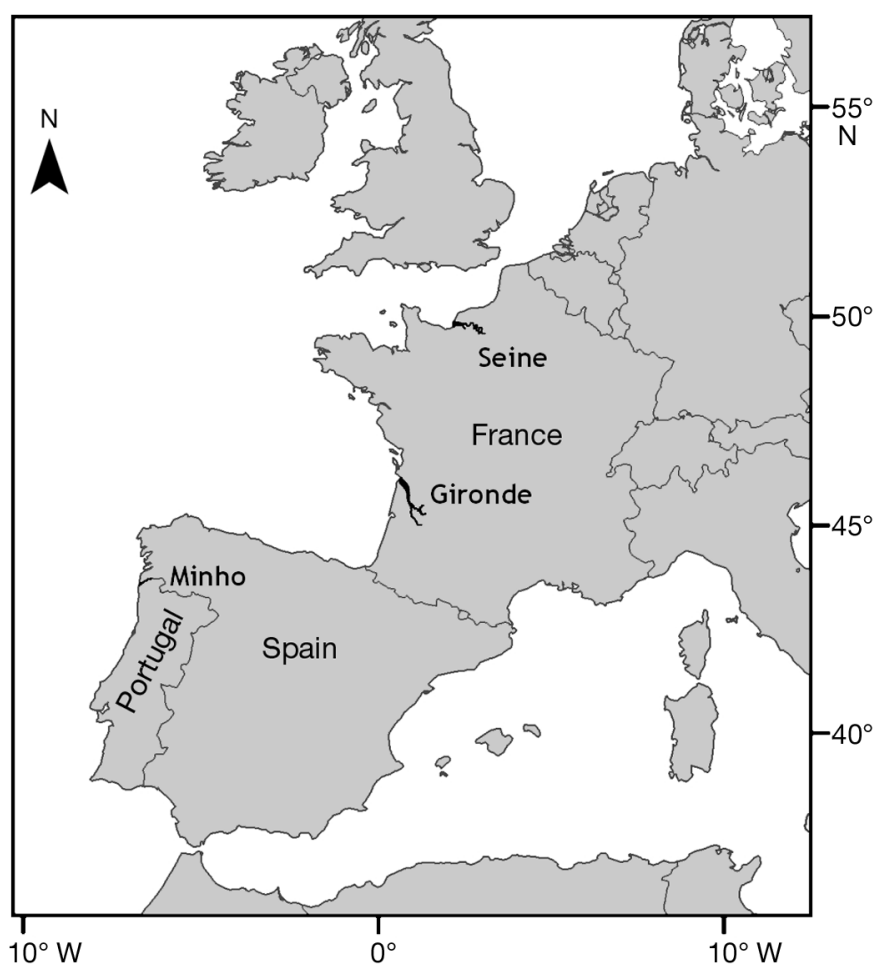

Fig. 1. Locations of European flounder sampling sites in each of the 3 studied catchment areas (a: Minho; b: Gironde; c: Seine), as noted by small rectangles in each catchment inset map 
form a salt wedge near the mouth of the estuary during periods of high river flow. The limit of tide penetration is $\sim 40 \mathrm{~km}$ inland, with the uppermost $30 \mathrm{~km} \mathrm{a}$ tidal freshwater wetland. The mean depth of the estuary is $2.6 \mathrm{~m}$, and the maximum depth is $\sim 26 \mathrm{~m}$ (Antunes et al. 2011). Average annual freshwater inflow is $300 \mathrm{~m}^{3} \mathrm{~s}^{-1}$ (Ferreira et al. 2003).

The coastal area adjacent to the Minho estuary has a narrow continental platform (Palenzuela et al. 2004), which varies between 30 and $75 \mathrm{~km}$ in width, and is influenced by the NW Iberian upwelling system, the northernmost limit of the Eastern North Atlantic upwelling system (Alvarez et al. 2008). The coastal upwelling occurs during spring and summer and is accompanied by northerly winds along the coast, although it sometimes occurs during winter. The summer upwelling introduces nutrient-rich and cold deep waters into the coastal estuarine ecosystems (Alvarez et al. 2008).

\section{Gironde estuary and adjacent coastal area}

The Gironde estuary is located on the SW Atlantic coast of France (Fig. 1.) and has an area of $\sim 625$ $\mathrm{km}^{2}$, with $9.7 \%$ of its area an intertidal zone. It is a well mixed mesotidal estuary, with tides varying between 2 and $5 \mathrm{~m}$ (Castaing 1981). The Gironde estuary is $\sim 150 \mathrm{~km}$ long. The annual average freshwater inflow varies between 800 and $1000 \mathrm{~m}^{3} \mathrm{~s}^{-1}$, with considerable variation between low $\left(270 \mathrm{~m}^{3}\right.$ $\mathrm{s}^{-1}$ ) and high discharge (1200 to $1500 \mathrm{~m}^{3} \mathrm{~s}^{-1}$ ) (SIE 2011).

The coastal area adjacent to the Gironde estuary has a $160 \mathrm{~km}$ wide continental platform and is a part of the Bay of Biscay. This coastal area has a mean depth of 30 to $50 \mathrm{~m}$ where the sediments consist of fine mud, the so-called 'vasière Ouest Gironde', stretching from the Gironde estuary to Pertuis de Maumusson. This coastal area is highly influenced by the Gironde estuary plume (Herbland et al. 1998).

Seine estuary and adjacent coastal area

The Seine estuary is located in N France (Fig. 1) and has an area of $\sim 282 \mathrm{~km}^{2}$. It is a well mixed macrotidal estuary, with tides varying between 3 and $8 \mathrm{~m}$ (Brenon \& Le Hir
1999). The Seine estuary is $\sim 160 \mathrm{~km}$ long. The annual average freshwater inflow is $\sim 450 \mathrm{~m}^{3} \mathrm{~s}^{-1}$, with considerable variation between low (100 to $200 \mathrm{~m}^{3} \mathrm{~s}^{-1}$ ) and high discharge (1500 to $2000 \mathrm{~m}^{3} \mathrm{~s}^{-1}$ ) (SIE 2011).

The coastal area adjacent to the Seine estuary is the Bay of the Seine, which forms a quadrilateral $\sim 5000 \mathrm{~km}^{2}$ in area measuring $\sim 50 \mathrm{~km}$ from north to south and $\sim 100 \mathrm{~km}$ from west to east, with mostly regular morphological features. Opening wide onto the central English Channel in the north, the Bay of the Seine never exceeds $30 \mathrm{~m}$ in depth. In the inshore coastal zones, especially in the western part of the bay (Bay of Veys) and in the eastern part adjacent to the Seine estuary, sediment consists mostly of fine sand and silty/muddy fine sands (Gentil \& Cabioch 1997).

\section{Sample collection and otolith preparation}

A total of 123 juvenile and adult flounder were collected for the present study in the Minho (44 samples), Gironde (47 samples) and Seine basins (32 samples) (see Table 1 and Fig. 1 for detailed information on the number of samples and sites sampled in each basin).

In the Minho estuary, fish were collected in October 2007 with a beam trawl in 2 sampling areas, one located in the freshwater tidal area and the other in the brackish area of the estuary, while fish from the northern Portuguese coast were purchased at the ¡Caminha (Portugal) fish market in December 2007 (Fig. 1a). In the Gironde estuary, fish were collected with a beam trawl from the estuarine brackish area in January 2005, while freshwater specimens were collected from the Dronne River using electro-fishing in September 2008 (Fig. 1b). In the Seine estuary, fish were collected with a beam trawl in 2 sampling

Table 1. Mean $( \pm 1 \mathrm{SD})$ total length $(\mathrm{cm})$, fresh weight $(\mathrm{g})$ and age $(\mathrm{yr})$ of European flounder collected at each sampling site in Minho, Gironde and Seine catchments. Number of fish (n) collected at each site and date of capture are also noted

\begin{tabular}{|lrcccc|}
\hline Location & $\mathrm{n}$ & $\begin{array}{c}\text { Date of } \\
\text { capture }\end{array}$ & $\begin{array}{c}\text { Total } \\
\text { length }(\mathrm{cm})\end{array}$ & $\begin{array}{c}\text { Fresh weight } \\
(\mathrm{g})\end{array}$ & $\begin{array}{c}\text { Age } \\
(\mathrm{yr})\end{array}$ \\
\hline Minho freshwater & 14 & Oct 2007 & $8.8 \pm 1.7$ & $11.1 \pm 1.8$ & $0.1 \pm 0.3$ \\
Minho estuary & 15 & Oct 2007 & $7.7 \pm 6.7$ & $15.2 \pm 8.3$ & $0.3 \pm 0.5$ \\
N Portuguese coast & 15 & Dec 2007 & $28.9 \pm 2.6$ & $275.5 \pm 104.3$ & $1.7 \pm 0.7$ \\
Gironde freshwater & 5 & Sep 2008 & $23.4 \pm 3.3$ & $158.0 \pm 60.2$ & $1.2 \pm 0.5$ \\
Gironde estuary & 42 & Jan 2005 & $27.4 \pm 2.2$ & $199.7 \pm 46.2$ & $2.1 \pm 0.7$ \\
Seine estuary & 3 & Jul 2000 & $32.0 \pm 4.3$ & $246.8 \pm 80.1$ & $2.7 \pm 0.5$ \\
Bay of the Seine & 28 & Jul 2007 & $28.5 \pm 3.9$ & $243.8 \pm 102.6$ & $1.7 \pm 0.8$ \\
& & & & & \\
\hline
\end{tabular}


areas: 1 coastal area (Antifert harbor) in July 2000 and 1 lower estuary area in July 2007 (Fig. 1C).

Flounder were measured $( \pm 1 \mathrm{~mm})$ and weighed $( \pm 0.1 \mathrm{~g})$, and otoliths were collected. The left otolith from each pair of otoliths was prepared for LA-ICPMS analysis. Each otolith was rinsed 3 times with Milli-Q water, dried and then embedded in epoxy resin. Otoliths were ground in the sagittal plane exposing the core (primordia) and all annuli. The ground otolith surfaces were polished $(1 \mu \mathrm{m}$ diamond paste) and finally ultra-sonically cleaned.

\section{Elemental analysis with LA-ICP-MS}

The concentrations of $\mathrm{Sr}, \mathrm{Ba}$ and $\mathrm{Ca}$ in the otoliths of flounder captured in the Minho estuary and adjacent coastal area were determined using a Thermo Finnigan Element 2 ICPMS coupled to a Merchantek LUV 213 Nd:YAG laser located at the University of Manitoba (Winnipeg, Canada). Instrument parameters and typical running conditions are summarized by Halden \& Friedrich (2008). A $12 \mu \mathrm{m}$ diameter beam and $2 \mu \mathrm{m} \mathrm{s}^{-1}$ scan speed were used to optimise spatial resolution and sensitivity for these otoliths. Continuous transects were ablated across the otoliths from the rostrum to post-rostrum edge through the core. Calcium at $40 \mathrm{wt} \% \mathrm{CaO}$ was used as an internal standard, and the external calibration was done using NIST glass 610 with the nominal values reported by Pearce et al. (1997). Scans of NIST 610 were performed after every 1 to 3 samples, depending on the time required for each sample. Measured trace element concentrations, standard deviations and detection limits were processed using GLITTER software (Van Achterberg et al. 2001).

The flounder otoliths from the Gironde and Seine estuaries were analyzed for $\mathrm{Sr}, \mathrm{Ba}$ and $\mathrm{Ca}$ across a transect perpendicular to the growth marks from the core to the edge. Element concentrations were determined using a ICP-MS - Elan DRC II (Perkin Elmer) coupled with a high repetition rate infra-red femtosecond laser ALFAMET (Alfamet, Novalase SA; Amplitude Systemes), with a pulse rate of $3 \mathrm{kHz}$, a power of $115 \mathrm{~mW}$ and ablation spot size of $20 \mu \mathrm{m}$. In addition, a low volume ablation cell $\left(3.7 \mathrm{~cm}^{3}\right)$ was used to minimize signal peak broadening and enhance the signal-to-noise ratio. Quantification of trace elements in otoliths was achieved by external calibration using a series of 13 coprecipitated carbonate pellets (Barats et al. 2007) ranging from 0.1 to $500 \mathrm{\mu g} \mathrm{g}^{-1}$. Matrix matching calibration was preferred over conventional NIST glass sample to en-

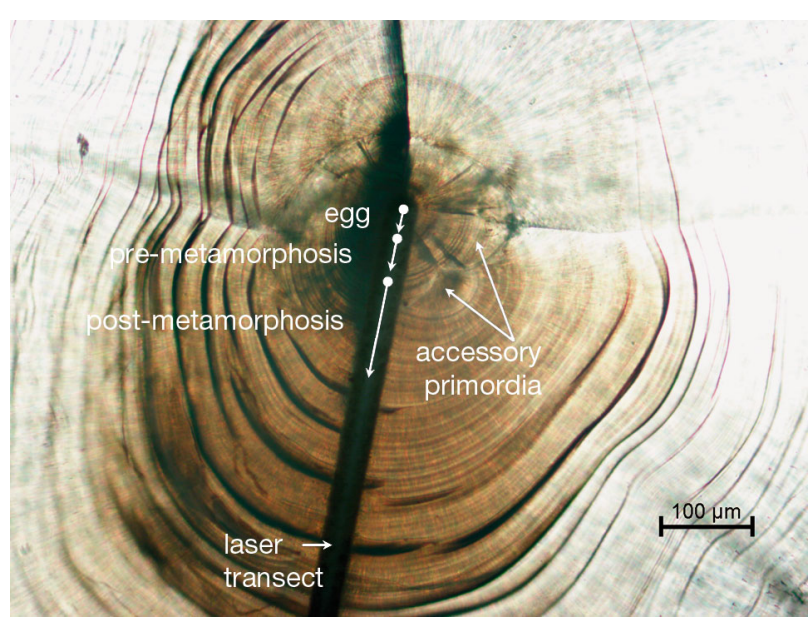

Fig. 2. Flounder sagittal otolith showing the egg, premetamorphosis and metamorphosis transects defined along the laser transect

sure the best accuracy. An otolith certified reference material (NIES 22) was also pelletized and used in the calibration curve. The calibration curve was systematically repeated every 12 samples using 3 enriched pellets and the CRM NIES 22 to correct for low-frequency drift resulting from changes in room temperature, plasma and electronics. Data obtained by both LA-ICP-MS instruments are comparable since they were both calibrated against known, certified reference material. The limits of detection $(\mu \mathrm{g}$ $\mathrm{g}^{-1}$ in otoliths) achieved in the present study were as follows: ${ }^{86} \mathrm{Sr}=3.6$ and ${ }^{138} \mathrm{Ba}=0.03$. These limits were based on a $3 \sigma$ criterion, where $\sigma$ is the standard deviation for the mean blank count of each isotope. All of the element concentrations in the otoliths were above the detection limits.

\section{Evaluation of flounder life history stages and age}

After LA-ICP-MS analysis, all otoliths were observed under a microscope to estimate fish age, according to ICES' ageing protocol (ICES 2008), and to determine the sections of the laser ablation transect corresponding to each life stage (i.e. egg, premetamorphosis or metamorphosis) (Fig. 2).

\section{Statistical analysis}

The principles of the statistical analysis that we used to analyze the $\mathrm{Sr}$ and $\mathrm{Ba}$ distributions along flounder otoliths (transects) were detailed by Fablet et al. (2007) and Daverat et al. (2011), who expanded 
a Bayesian labeling method from a mono-elemental transect (Sr:Ca) (Rabiner 1989) to a multi-elemental transect ( $\mathrm{Sr}: \mathrm{Ca}$ and $\mathrm{Ba}: \mathrm{Ca}$ ) to assign retrospective fish habitat use. In our study, for each individual lifehistory transect, as inferred from $\mathrm{Sr}: \mathrm{Ca}$ and $\mathrm{Ba}: \mathrm{Ca}$ ratios, a calibration over time was performed in MATLAB® to obtain Sr:Ca and Ba:Ca time series. For each otolith, annual ring positions along the transect axis, acquired with respect to the distance to the accessory primordium, were used as time references to transform Sr:Ca and Ba:Ca series to time series using a linear interpolation. Even though flounder otoliths have a seasonal deposition, the linear interpolation assumes constant growth over the year, but assigning a chemical signature or habitat to a certain season (growth period) is not an objective of the present work, so this methodology does not invalidate our analysis. The time series were interpolated at a monthly precision, corresponding to 12 samplings in between 2 annual rings; thus, hereafter, this time axis is referred as the 'age axis' because it refers to the time spent from metamorphosis.

As previously mentioned, we used a Bayesian labeling framework to assign habitats to the $\mathrm{Sr}: \mathrm{Ca}$ and Ba:Ca individual time series to retrieve retrospective habitat use. There was no direct validation because the sample did not contain any fish that could be geolocated with a direct method throughout their entire life. The challenge of otolith microchemistry methods is to assign habitat to chemical composition series using all available knowledge. One major hypothesis used was that coupled $\mathrm{Sr}: \mathrm{Ca}$ and $\mathrm{Ba}: \mathrm{Ca}$ measures can be regarded as a proxy of the habitat or saline compartment. The model also considers that $\mathrm{Sr}: \mathrm{Ca}$ and Ba:Ca signatures may have slight seasonal variations following river water discharge and that fish age could have an effect on habitat assignment (ontogenetic effect). Then, a hidden Markov chain model was used to account for the nature of each individual fish movement. This meant that the model considered each individual Sr:Ca and Ba:Ca time series as a whole. The principle was that the probability of a fish to go from one habitat to another habitat at time $t$ was dependent on the habitat used at time $t-1$ and on the assigned habitat at time $t+1$. This procedure is called a Bayesian labeling issue, which is illustrated by the following examples: (1) the probability for a fish to go from the sea to the river without being observed in the estuary was very low, and (2) as fish got older, they tended to be more sedentary. The hidden Markov chain algorithm (Rabiner 1989) retrieved the most probable individual habitat used (or sequences of habitats) using a backward and for- ward fitting (each time step was dependant on the subsequent and previous steps). There is no p-value associated with the results because the data concern the most probable habitat sequence for each fish, nor was there any level of confidence since there is no comparison between otolith microchemistry and the habitats used by fish during their life.

We fitted 3 Gaussian mixture models to the $3 \mathrm{Sr}: \mathrm{Ca}$ and Ba:Ca distributions (the distribution of all points and all individuals for the Minho, Gironde and Seine) to acquire a probability distribution for $\mathrm{Sr}: \mathrm{Ca}$ and $\mathrm{Ba}$ :Ca values to be assigned to 3 habitat categories according to salinity: (1) coastal area, (2) brackish estuary and (3) freshwater tidal area. We further modeled the distribution of the $\mathrm{Sr}: \mathrm{Ca}$ and $\mathrm{Ba}: \mathrm{Ca}$ signatures for each habitat as a Gaussian distribution parameterized by a linear model (function of season and age of the fish). For the Gironde estuary, the range of $\mathrm{Sr}: \mathrm{Ca}$ and $\mathrm{Ba}: \mathrm{Ca}$ values measured in a validation experiment (Daverat et al. 2011) was used to allocate an habitat type (i.e. coast, brackish estuary or freshwater tidal area) to a Gaussian mode. For the Minho and Seine samples, it was verified that the $\mathrm{Sr}$ and $\mathrm{Ba}$ otolith composition at the edge of the otolith was consistent with the expected gradient of $\mathrm{Sr}$ and Ba values at the location of capture (i.e. an expected highest value of $\mathrm{Sr}$ and lowest value of $\mathrm{Ba}$ in coastal habitat and lowest value of $\mathrm{Sr}$ and highest value of $\mathrm{Ba}$ in freshwater habitat). The analysis of individual patterns of habitat use was set with a Bayesian labeling issue, made from the series of $\mathrm{Sr}: \mathrm{Ca}$ and $\mathrm{Ba}: \mathrm{Ca}$ measures and according to the maximum a posteriori criterion. Thus, Bayesian labeling allowed retrieval of the temporal habitat sequence for each specimen, i.e. coast (C), brackish estuary (E) and the freshwater tidal area (F). To account for realistic temporal dynamics of movement among habitats, first-order Gaussian hidden Markov models (Rabiner 1989) were used. The non-supervised classification of the habitat use patterns for each species was then performed using a method designed for speech analysis (Rabiner 1989). The habitat use patterns were defined as the sequence of the successive habitats visited by the fish (e.g. the movement pattern issued from habitat sequence CCCCEEEECCCCC was CEC). Given the whole otolith set, the automated and unsupervised classification of individual habitat use patterns could be determined as well as the relative frequencies of these categories of habitat use patterns. In contrast to an expert-driven analysis, the non-supervised categorization does not exploit any prior knowledge, typically some expert knowledge, on the expected categories to be defined. The cate- 
gorization is only issued from data characteristics and statistics. As the habitat sequences were calibrated over time, a variety of measures could also be defined to characterize individual life traits, such as the distribution of the age at entrance into freshwater habitat. Data analyses also included the data corresponding to flounder larval development.

\section{RESULTS}

\section{Reconstructed habitats of flounder during ontogeny}

The most common habitat signatures assigned to the egg stage (hereafter, egg signature) for the 3 basins were brackish water and coastal (Fig. 3). A freshwater signature was only observed in flounder collected in the Gironde estuary (18\%) (Fig. 3b) and in the Seine coast (28\%) (Fig. 3c).

The most common habitat signatures assigned to flounder during the pre-metamorphic and metamorphic stages varied between the 3 basins (Fig. 3). In the Minho area, the most common pre-metamorphic habitat assigned to flounder collected in the 3 habitats was brackish water (54 to $100 \%$ ) (Fig. 3a); in the Gironde, the coastal habitat was the most frequent and varied between 41 and 100\%) (Fig. 3b), and in the Seine, both brackish and freshwater signatures had similar relative frequencies that varied between 39 and $50 \%$ (Fig. 3c).

During metamorphosis, the most common habitat for Minho flounder was brackish water (67 to $92 \%$ ) (Fig. 3a), for Gironde flounder, it was the coast ( 81 to $100 \%$ ) (Fig. 3b), and for Seine flounder, it was freshwater habitats (57 to $100 \%$ ) (Fig. 3c).

\section{Analysis of flounder life histories after metamorphosis}

The diversity of flounder life histories after metamorphosis was similar among basins: 13 different life histories in the Minho and Gironde basins (Fig. 4a,b) and 14 in the Seine basin (Fig. 4c).
In the Minho basin, the most frequent life history for flounder collected in the coast and estuary was EC $(27 \%)$, while for those flounder collected in the freshwater tidal area, it was F (86\%) (Fig. 4a). In the Gironde basin, the most frequent life history for fishes collected in the estuary was FEC (38\%), while for those flounder collected in the freshwater tidal area, it was F (80\%) (Fig. 4b). In the Seine basin, the most frequent life history for fishes collected in the coast was FE (17\%) and EFEC (17\%), while for those flounder collected in the estuary, it was FEC, FC and C (33\%) (Fig. 4c).

Permanent residency in 1 habitat was registered in all 3 basins (Fig. 4). In the Minho, $13 \%$ of flounder collected in the coast had permanent brackish estuarine residency, $20 \%$ and $13 \%$ of flounder collected in the brackish part of the estuary had permanent freshwater and brackish estuarine residency, respectively, and $86 \%$ of flounder collected in the freshwater tidal area had permanent freshwater residency (Fig. 4a). In the

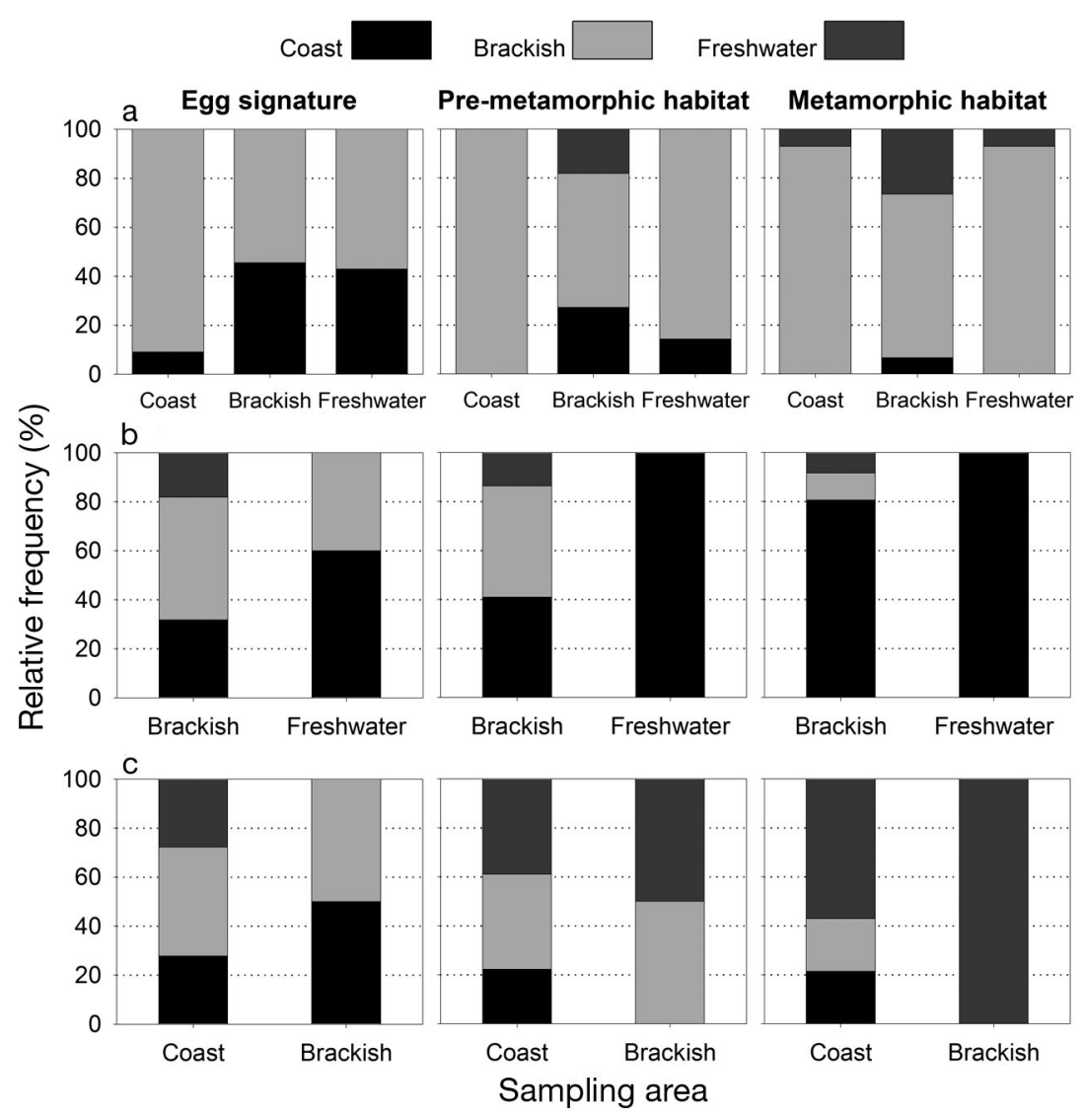

Fig. 3. Percentage of European flounder otolith signatures or reconstructed habitats (coast, brackish and freshwater tidal or not tidal) for the egg, premetamorphic and metamorphic stages in (a) Minho, (b) Gironde and (c) Seine catchments. The number of samples collected in each site is detailed in Table 1 

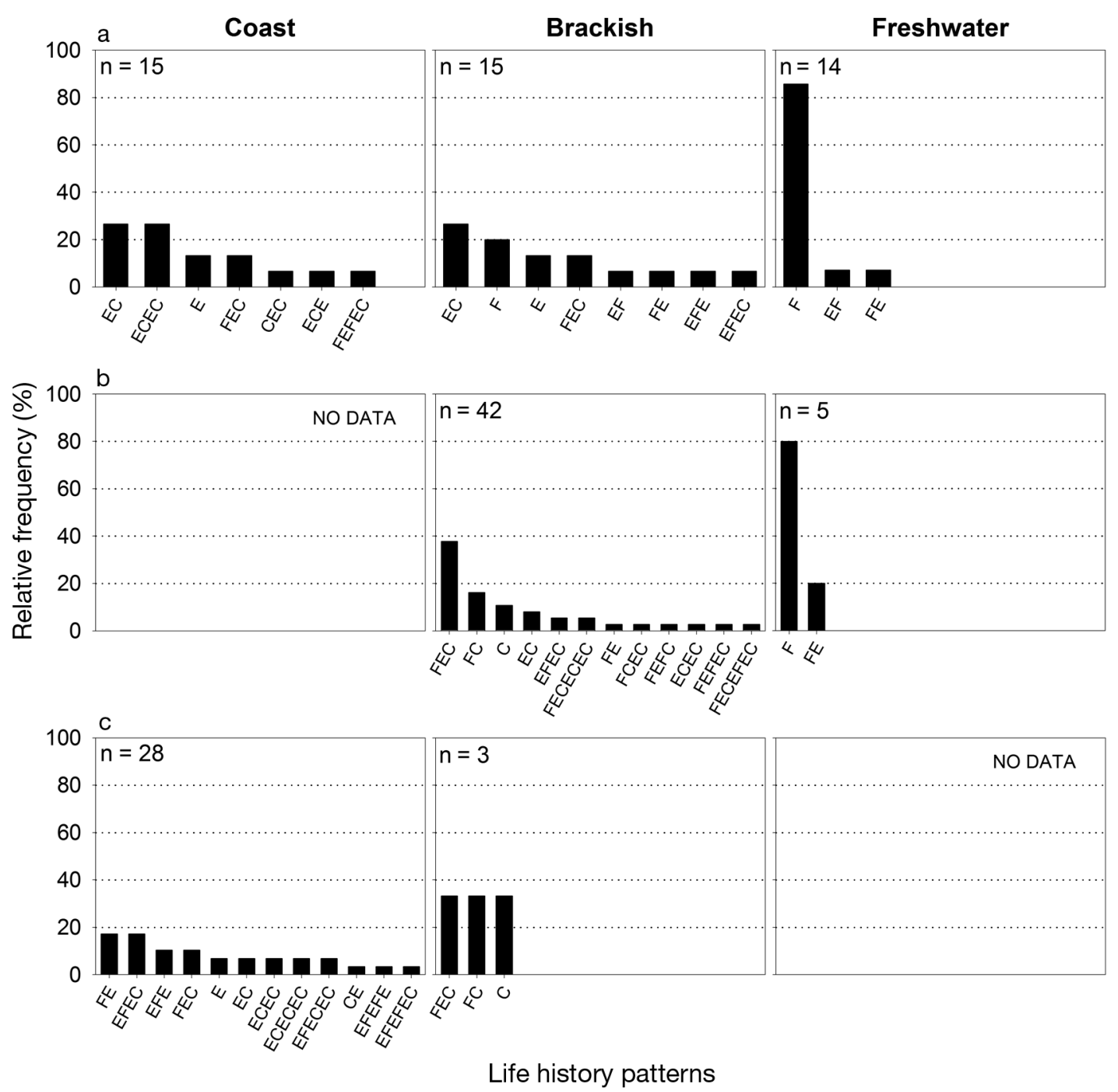

Fig. 4. Percentage of European flounder habitat use patterns during their life after metamorphosis, estimated by the distribution of $\mathrm{Sr}: \mathrm{Ca}$ and $\mathrm{Ba}: \mathrm{Ca}$ signatures for each habitat as a Gaussian distribution parameterized by a linear model specific to each catchment (a: Minho; b: Gironde; c: Seine). Each habitat sequence is represented by the successive types of habitats (C: coast; E: estuary; F: freshwater) visited by the fish, e.g. the habitat sequence EEEEFFFEE would be represented by the sequence EFE. The frequencies of habitat use patterns are shown in decreasing order

Gironde, $11 \%$ of flounder collected in the estuary had permanent coastal residency, while $80 \%$ of flounder collected in freshwater had permanent freshwater residency (Fig. 4b). In the Seine, $7 \%$ of flounder collected in the coast had permanent brackish estuarine residency, and $33 \%$ of flounder collected in the estuary had permanent coastal residency (Fig. 4c).

\section{Age of flounder when migrating to freshwater habitats}

Most Minho flounder migrated to freshwater before reaching $0.5 \mathrm{yr}$ old (Fig. 5a). In the Gironde, flounder migrating from the coast reached freshwater before $0.5 \mathrm{yr}$ old, while those migrating from the estuary continued migrating to freshwater until $1.5 \mathrm{yr}$ old (Fig. 5b). In the Seine, flounder migrating from the coast into freshwater reached maximum frequencies at the age $1.3 \mathrm{yr}$ old, while most flounder migrating from the estuary reached freshwater before 0.5 yr old (Fig. 5c).

\section{DISCUSSION}

Summers (1979) established that European flounder exhibit catadromous behavior, consisting of 
development and maturation in brackish and freshwater ecosystems and migration to marine environments to reproduce. Although no other studies have definitively shown that the species exhibits this behavior, it is widely accepted (e.g. Borsa et al. 1997,
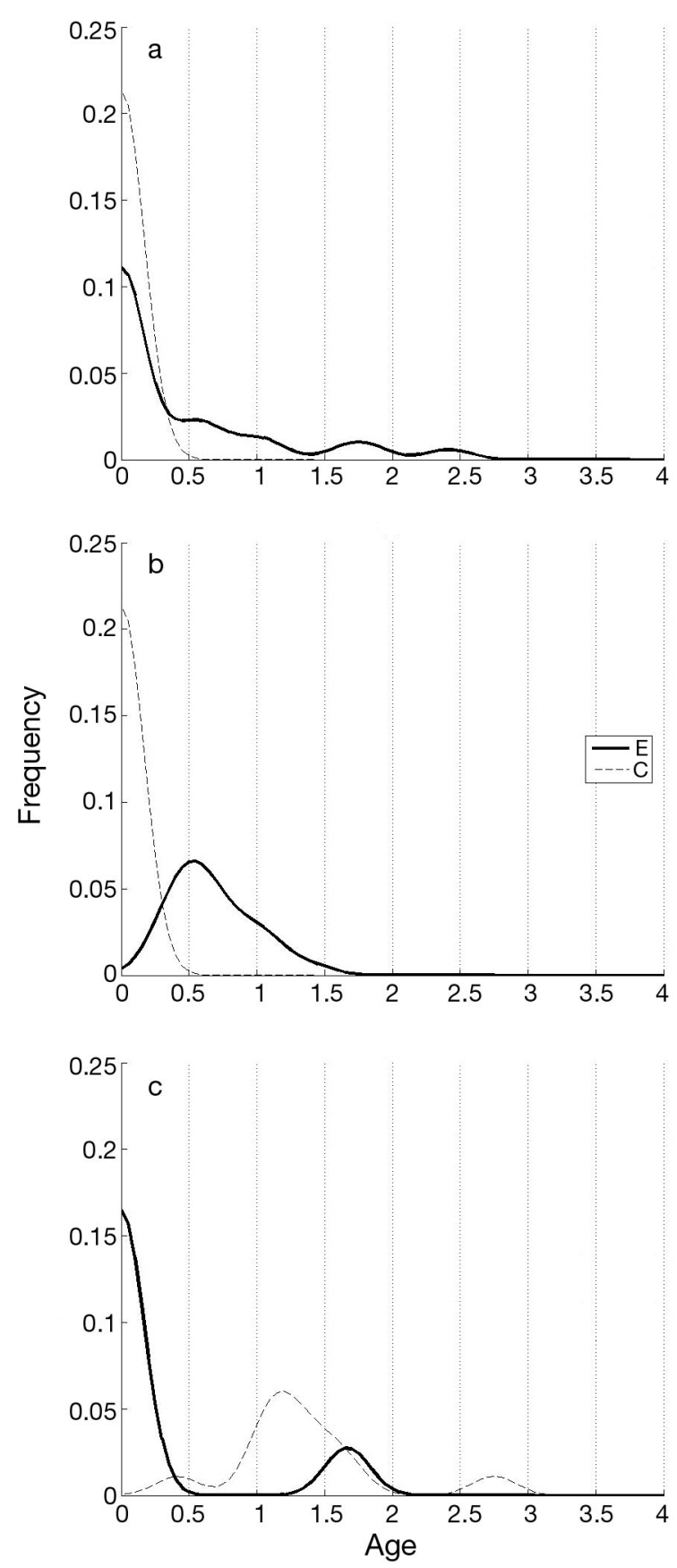

Fig. 5. Age distributions of European flounder collected at (a) Minho, (b) Gironde and (c) Seine catchments at their arrival in freshwater habitats for fish migrating from the estuary (E) and coast (C)
Minier et al. 2000, Marchand et al. 2003, Franco et al. 2008). However, there has been no broad-scale, multi-site study showing the existence of a generalized catadromous strategy across the entire distribution range of the species. Our study, with analysis of individuals from a limited part of the flounder distributional range, reveals that the catadromous strategy is one of many life history strategies used by European flounder.

\section{Location of flounder spawning environments}

Otoliths of embryos are formed shortly after egg fertilization (Zhang \& Runham 1992) and are imprinted with the chemical signature of the water in which the eggs were hydrated (marine, brackish or freshwater environments), at least for salmonids (e.g. Zimmerman \& Reeves 2000, Miller \& Kent 2009). In salmonids, the progeny of females that matured in seawater (i.e. eggs developed in a high Sr environment) and spawned in freshwater environments (i.e. sea-run mothers) showed an elevated Sr concentrations in the otolith core followed by an abrupt decrease of Sr concentration (e.g. Kalish 1990, Volk et al. 2000). A similar pattern was found in flounder otoliths, which was also attributed to sea-run mothers (Morais et al. 2011). Thus, the assignment of a coastal signature in the otoliths must be made with caution since a 'maternal' effect caused by a marine mother may exist.

Even if the sea-run mother hypothesis is incorrect, and the elevated levels observed in the otolith's core correspond to an artifact formed in the otolith primordium, we hypothesize that the environment attributed to pre-metamorphic larvae should represent the area where hatching occurred, due to the reduced period elapsed from fertilization to hatching. River inflow and predominant ocean currents must also be considered. In our study, the egg signatures of flounder collected in freshwater in the Gironde area were $60 \%$ coast and $40 \%$ brackish, while the coast was the only environment attributed to premetamorphic flounder collected in freshwater. Our interpretation is that all flounder collected in freshwater hatched in the coast area, with $40 \%$ of them being the progeny of mothers migrating from a brackish ecosystem. As a result of this hypothetical interpretation, we suggest that spawning occurred predominantly in a brackish water environment in the Minho area, with some progenitors migrating from the coast to spawn in the estuary. Although the number of flounder collected in freshwater and 
brackish waters was small in the Gironde and Seine, we still interpreted the signatures as flounder hatched similarly in coastal, brackish and freshwater environments. More study is required to validate this interpretation.

Our interpretations suggest that European flounder is not an exclusively catadromic species (e.g. Summers 1979, Franco et al. 2008). The estuarine spawning of flounder has to be confirmed by sampling eggs in the different habitats within the river basins. In support of our interpretations, 2 sympatric flounder populations were observed to have different reproductive strategies and spawning habitats in the Baltic Sea to cope with the prevailing low salinity conditions (Florin \& Höglund 2008). The northern population produces demersal eggs in low salinities in coastal areas and on banks, while the central/ southern population produces pelagic eggs mainly in areas of higher salinities and in the deepest basins (Nissling et al. 2002). The observations from the Baltic Sea flounder and those of our study strongly suggest that flounder are able to use coastal and estuarine spawning habitats at various sites along their distribution range, thus further supporting the suggestion that catadromy is facultative for European flounder.

\section{Location of flounder nursery grounds}

The interpretation of the flounders' otolith microchemistry data as a proxy for nursery environments is subject to caution because ontogeny and environment both influence the incorporation of Sr and Ba in otoliths during pre-metamorphosis and metamorphosis. The Sr:Ca otolith signature of common sole Solea solea larvae reared in constant salinity decreased during metamorphosis, while field-reared larvae Sr:Ca otolith signatures were also controlled by the variations of salinity of the rearing environment (de Pontual et al. 2003). Previous work showed that Ba incorporation into otoliths was negatively correlated to growth rate during ontogeny (Walther et al. 2010), while other studies concluded that Ba incorporation was mostly environmentally driven (Elsdon \& Gillanders 2003a,b). For European flounder, there is no evidence to date that suggest an ontogeny effect on the incorporation of elements to the otolith (Morais et al. 2011). However, it is unlikely that ontogeny has a greater effect than the surrounding environment. Thus, we inferred that flounder used 3 distinct habitats (i.e. marine, brackish and freshwater environments) in the Minho, Gironde and Seine catchments during pre-metamorphosis and metamorphosis. The capture location of flounder did not pre-establish the assignment of pre-metamorphic and metamorphic habitats (nor egg signature). This observation emphasizes the importance of habitat connectivity for the successful recruitment of flounder, similar to other estuarine-dependent fishes (Gillanders 2005, Ray 2005).

In our study, flounder populations were estuarine dependent (brackish and freshwater estuarine habitats) where the probability for direct settlement was high (i.e. estuarine nursery recruitment has to occur before settlement), mainly in the Minho and Seine populations. Direct settlement would be advantageous given that larvae or juveniles would not need to expend energy in osmoregulation and in migrating to nursery habitats (Shiao et al. 2003) and would also benefit from increased prey availability and predator refugia (Cyrus \& Blaber 1987). Flounder larvae at the pre-metamorphosis and metamorphosis stages in freshwater environments were less abundant in the Minho and Gironde relative to Seine flounder at the same stages. Nonetheless, the arrival of flounder in freshwater habitats occurred at an early age in the 3 catchments, similar to results from several field studies sampling flounder larvae and juveniles in tidal freshwater areas in the Minho (Freitas et al. 2009) and Gironde estuaries (M. Lepage pers. comm.), and also in other estuaries such as the Canche and Otie (both in France) (Amara et al. 2009). Further, the assignment of both the pre-metamorphic and metamorphic stages is supported by previous work that has documented flounder in estuarine ichthyoplankton (Ramos et al. 2010). However, we do not exclude the possibility that some of these flounder resided in a coastal brackish environment, namely in river plumes. River plumes also influence otolith microchemistry (Patterson et al. 2004, Schaffler et al. 2009), and thus, the signature of this habitat could bias our interpretation. River plumes can also be suitable habitats for pre-metamorphic and metamorphic larvae, similarly to estuarine nurseries, because they also provide enough food for larvae to sustain enhanced growth rates (De Vries et al. 1990). Those larvae and juveniles that have not made direct settlement and/or rapid settlement into an estuarine nursery could use selective tidal stream transport to migrate upstream into an estuary (Bos 1999, Jager 1999). The intricate relationship between otolith microchemistry, river plume and habitat use/natal origin suggests that further studies are required. These can be conducted since analytical improvements now allow 
distinguishing fishes' natal origin even when the abiotic difference between locations is low (Schaffler et al. 2009).

\section{Ecological significance of flounder's diversified life history patterns}

The diversity of flounder life history patterns found in each of the 3 catchments, differing both in number and frequency, was one unpredicted result of our study. The plasticity exhibited by flounder regarding their spawning grounds, environments used during ontogeny and the age at migration to freshwater was also unexpected. These results were similar to the life history patterns of flounder in the Baltic Sea (Nissling et al. 2002, Florin \& Höglund 2008). Whether flounder life history pattern plasticity was mostly influenced by environment, genetics or both factors was not within the scope of our study. However, for other diadromous fishes such as eel and salmon, the plasticity of their life history patterns (e.g. spawning environments, and habitat use) could be explained by a conditional strategy (Hutchings \& Myers 1988, Tsukamoto et al. 1998, Daverat et al. 2006). The conditional strategy theory predicts that genetically monomorphic individuals select a tactic, depending on their status or condition, to acquire higher fitness (Gross 1996). Since each tactic has unequal fitness, the one that procures better fitness will dominate (Thibault et al. 2007). For example, the plasticity of American eel Anguilla rostrata life history patterns was not related to its status (size, sex or age) prior to migration (Thibault et al. 2007) but to environmental conditions, similarly to A. anguilla and Japanese eel A. japonica (Daverat et al. 2006). However, the phenotypic reproductive plasticity of Atlantic salmon Salmo salar has a genetic basis, but at the individual level, the environment can still be a driving force (Piché et al. 2008).

For flounder, the interactive effects of temperature, food availability and substrate type are important factors driving life history patterns (Lassalle \& Rochard 2009, Camp et al. 2011). However, salinity and dissolved oxygen might not be the most important environmental cues since flounder is a euryhaline species (Summers 1979, Nissling et al. 2002, Freitas et al. 2009), even able to tolerate hypoxic conditions without compromising osmoregulation (Lundgreen et al. 2008). Telemetry studies conducted in the Seine during summer showed that adult flounder preferred colder freshwater habitats at the confluences of Seine tributaries, $\sim 4^{\circ} \mathrm{C}$ colder than warmer sites in the lower part of the Seine main river and tributaries (E. Rochard pers. comm.). In the Minho estuary, the abundance of juveniles is greater in warmer freshwater tidal habitats (Freitas et al. 2009), up to $9^{\circ} \mathrm{C}$ warmer during summer coastal upwelling events, than in the brackish estuary (E. Dias unpubl. data), allowing juveniles to attain faster growth rates (Fonds et al. 1992). Other factors than temperature, such as juvenile density and habitat contamination, may also interact (Gilliers et al. 2006, Amara et al. 2009) and influence flounder life history.

Our current data are insufficient to assess a latitudinal trend in life history tactics, as observed for brown trout Salmo trutta, which is predominantly anadromous in cooler, northern latitudes and predominantly non-anadromous in southern latitudes (McDowall 1997). We were unable to assess the relationship between plasticity of life history patterns and the area of the river basin and estuary, continental platform width or river discharge. These factors are among the main factors influencing the structure of estuarine fish assemblages (Nicolas et al. 2010) and flounder juvenile recruitment (Martinho et al. 2009). The inter-annual variability of river discharge may be an indirect driver of flounder life history plasticity, probably due to its control in setting estuarine productivity (Whitfield 1994, Loneragan \& Bunn 1999) and in influencing the rate of direct and indirect recruitment of fishes in estuaries (Chícharo et al. 2001). The management of European flounder estuarine fisheries relies on accurate, multidisciplinary scientific data. Currently, it appears that management of these fisheries cannot rely either on a single country or general European Union policy because the plasticity of flounder life histories varied markedly among proximate estuaries. This type of policy can induce selective fishing mortality on individuals that use 1 particular migratory tactic, with unpredictable consequences for flounder genetic diversity and stock structure (Olsen et al. 2004, Thériault et al. 2008). At the local scale, sustainable management of flounder stocks is contingent on both connectivity among coastal, brackish and freshwater habitats, which in dam-regulated ecosystems depends on maintaining water discharge below critical levels (Morais et al. 2009), while from a metapopulation perspective, it is important to understand the roles of spatial heterogeneity in population structure and connectivity (Smedbol et al. 2002). Ultimately, flounder fishery management must be supported by solid population trait data, and future work should investigate the mechanisms underlying migratory plasticity in European flounder. 
Acknowledgements. Financial and technical support for the present work was supported by the programs THALASSOTOQUE (FEDER and CPER programs of Region Aquitaine, France), ANR-07-VULN-03 EEL-Scope, THALASSOTOK Seine Aval and Investigação na Pré-Graduação (IPG75, Universidade do Porto, Portugal). Most flounder otoliths from the Gironde and Seine were kindly provided by J. Laroche and L. Quiniou from Brest University. We are grateful to J. Bigot, R. Le Barh and B. Ballion for their assistance on board of the Esturial research vessel, and to A. Amorim, F. Carvalho, T. Santos (University of Porto), R. Wastle (Fisheries and Oceans Canada, Winnipeg, Canada) and Z. Song (University of Manitoba, Winnipeg, Canada) for their assistance with the Minho samples. We are indebted to L. Lanceleur and J. Schaeffer from the University of Bordeaux I (EPOC laboratory), who performed the water analysis of $\mathrm{Sr}$ and $\mathrm{Ba}$ concentrations within the EELSCOPE project framework, and to A. Just for making the map of the study area. P.M. has a post-doctoral scholarship grant (SFRH/BPD/40832/2007) financed by Fundação para a Ciência e a Tecnologia (Portugal). We also appreciated the comments and suggestions made by 3 anonymous reviewers and the editor.

\section{LITERATURE CITED}

Alvarez I, Gomez-Gesteira M, de Castro M, Novoa EM (2008) Ekman transport along the Galician Coast (NW Spain) calculated from QuikSCAT winds. J Mar Syst 72: 101-115

Alves AM (1996) Causas e processos da dinâmica sedimentar na evolução actual do litoral do Alto Minho. PhD thesis, Universidade do Minho

Amara R, Selleslagh J, Billon G, Minier C (2009) Growth and condition of 0-group European flounder, Platichthys flesus as indicator of estuarine habitat quality. Hydrobiologia 627:87-98

Antunes C, Araújo MJ, Braga C, Roleira A and others (2011) Plano de gestão da enguia europeia Anguilla anguilla (L.), no troço internacional do rio Minho. Projecto MiñoMinho. Project Report. CIIMAR \& Universidade de Santiago de Compostela, Porto/Santiago de Compostela

> Arai T, Goto A, Miyazaki N (2003) Migratory history of the threespine stickleback Gasterosteus aculeatus. Ichthyol Res 50:9-14

> Arai T, Yang J, Miyazaki N (2006) Migration flexibility between freshwater and marine habitats of the pond smelt Hypomesus nipponensis. J Fish Biol 68:1388-1398

Barats A, Pécheyran C, Amouroux D, Dubascoux S, Chauvaud L, Donard O (2007) Matrix-matched quantitative analysis of trace-elements in calcium carbonate shells by laser-ablation ICP-MS: application to the determination of daily scale profiles in scallop shell (Pecten maximus). Anal Bioanal Chem 387:1131-1140

> Barriga JP, Battini MA, Cussac VE (2007) Annual dynamics variation of a landlocked Galaxias maculatus (Jenyns 1842) population in a Northern Patagonian river: occurrence of juvenile upstream migration. J Appl Ichthyol 23: 128-135

> Beaumont WRC, Mann RHK (1984) The age, growth and diet of a freshwater population of the flounder, Platichthys flesus (L), in southern England. J Fish Biol 25: 607-616

Begg GA, Campana SE, Fowler AJ, Suthers IA (2005) Otolith research and application: current directions in innovation and implementation. Mar Freshw Res 56: 477-484

Borsa P, Blanquer A, Berrebi P (1997) Genetic structure of the flounders Platichthys flesus and P. stellatus at different geographic scales. Mar Biol 129:233-246

Bos AR (1999) Tidal transport of flounder larvae (Pleuronectes flesus) in the Elbe River, Germany. Arch Fish Mar Res 47:47-60

Brenon I, Le Hir P (1999) Modelling the turbidity maximum in the Seine Estuary (France): identification of formation processes. Estuar Coast Shelf Sci 49:525-544

- Camp AL, Ryer CH, Laurel B, Seals K (2011) Effect of nursery habitat on density-dependent habitat selection in juvenile flatfish. J Exp Mar Biol Ecol 404:15-20

> Campana SE (1999) Chemistry and composition of fish otoliths: pathways, mechanisms and applications. Mar Ecol Prog Ser 188:263-297

> Campana SE (2005) Otolith science entering the 21st century. Mar Freshw Res 56:485-496

Castaing P (1981) Le transfert à l'océan des suspensions estuariennes, cas de la Gironde. PhD thesis, University of Bordeaux I

> Chapman A, Morgan DL, Beatty SJ, Gill HS (2006) Variation in life history of land-locked lacustrine and riverine populations of Galaxias maculatus (Jenyns 1842) in Western Australia. Environ Biol Fishes 77:21-37

Chícharo L, Chícharo MA, Esteves E, Andrade JP, Morais P (2001) Effects of alterations in freshwater supply on the abundance and distribution of Engraulis encrasicolus in the Guadiana Estuary and adjacent coastal areas of south Portugal. Ecohydrol Hydrobiol 1:341-345

Cyrus DP, Blaber SJM (1987) The influence of turbidity on juvenile marine fishes in estuaries. Part 2. Laboratory studies, comparisons with field data and conclusions. J Exp Mar Biol Ecol 109:71-91

> Daverat F, Limburg KE, Thibault I, Shiao JC and others (2006) Phenotypic plasticity of habitat use by three temperate eel species, Anguilla anguilla, A. japonica and A. rostrata. Mar Ecol Prog Ser 308:231-241

> Daverat F, Martin J, Fablet R, Pécheyran C (2011) Colonisation tactics of three temperate catadromous species, eel Anguilla anguilla, mullet Liza ramada and flounder Plathychthys flesus, revealed by Bayesian multielemental otolith microchemistry approach. Ecol Freshw Fish 20:42-51

de Pontual H, Lagardère F, Amara R, Bohn M, Ogor A (2003) Influence of ontogenetic and environmental changes in the otolith microchemistry of juvenile sole (Solea solea). J Sea Res 50:199-210

> De Vries DA, Grimes CB, Langi KL, White DB (1990) Age and growth of king and Spanish mackerel larvae and juveniles from the Gulf of Mexico and U.S. South Atlantic Bight. Environ Biol Fishes 29:135-143

Elliott M, Dewailly F (1995) The structure and components of European estuarine fish assemblages. Neth J Aquat Ecol 29:397-417

Elliott M, Whitfield AK, Potter IC, Blaber SJM, Cyrus DP, Nordlie FG, Harrison TD (2007) The guild approach to categorizing estuarine fish assemblages: a global review. Fish Fish 8:241-268

- Elsdon TS, Gillanders BM (2003a) Relationship between water and otolith elemental concentrations in juvenile black bream Acanthopagrus butcheri. Mar Ecol Prog Ser 260:263-272

Elsdon TS, Gillanders BM (2003b) Reconstructing migratory 
patterns of fish based on environmental influences on otolith chemistry. Rev Fish Biol Fish 13:217-235

> Elsdon TS, Gillanders BM (2006) Temporal variability in strontium, calcium, barium, and manganese in estuaries: implications for reconstructing environmental histories of fish from chemicals in calcified structures. Estuar Coast Shelf Sci 66:147-156

- Elsdon TS, Wells BK, Campana SE, Gillanders BM and others (2008) Otolith chemistry to describe movements and life-history parameters of fishes: hypotheses, assumptions, limitations and inferences. Oceanogr Mar Biol Annu Rev 46:297-330

Fablet R, Daverat F, De Pontual H (2007) Unsupervised Bayesian reconstruction of individual life histories from otolith signatures: case study of $\mathrm{Sr}$ :Ca transects of European eel (Anguilla anguilla) otoliths. Can J Fish Aquat Sci 64:152-165

Ferreira JG, Simas T, Nobre A, Silva MC, Schifferegger K, Lencart-Silva J (2003) Identification of sensitive areas and vulnerable zones in transitional and coastal Portuguese systems. Application of the United States National Estuarine Eutrophication Assessment to the Minho, Lima, Douro, Ria de Aveiro, Mondego, Tagus, Sado, Mira, Ria Formosa and Guadiana systems. INAG/ IMAR Tech Rep

Florin AB, Höglund J (2008) Population structure of flounder (Platichthys flesus) in the Baltic Sea: differences among demersal and pelagic spawners. Heredity 101:27-38

Fonds M, Cronie R, Vethaak AD, Van der Puyl P (1992) Metabolism, food consumption and growth of plaice (Pleuronectes platessa) and flounder (Platichthys flesus) in relation to fish size and temperature. Neth J Sea Res 29:127-143

Franco A, Elliott M, Franzoi P, Torricelli P (2008) Life strategies of fishes in European estuaries: the functional guild approach. Mar Ecol Prog Ser 354:219-228

Freitas V, Costa-Dias S, Campos J, Bio A, Santos P, Antunes C (2009) Patterns in abundance and distribution of juvenile flounder, Platichthys flesus, in Minho estuary (NW Iberian Peninsula). Aquat Ecol 43:1143-1153

Gentil F, Cabioch L (1997) Carte des peuplements macrobenthiques de la Baie de Seine et Manche centrale sud. Carte et notice explicative de la carte. Edition de la Station Biologique de Roscoff

Gillanders BM (2005) Using elemental chemistry of fish otoliths to determine connectivity between estuarine and coastal habitats. Estuar Coast Shelf Sci 64:47-57

Gilliers C, Le Pape O, Désaunay Y, Morin J, Guérault D, Amara R (2006) Are growth and density quantitative indicators of essential fish habitat quality? An application to the common sole Solea solea nursery grounds. Estuar Coast Shelf Sci 69:96-106

> Gross MR (1996) Alternative reproductive strategies and tactics: diversity within sexes. Trends Ecol Evol 11:92-98

> Halden NM, Friedrich LA (2008) Trace-element distribution in fish otoliths: natural markers of life histories, environmental conditions and exposure to tailings effluence. Mineral Mag 72:593-605

> Herbland A, Delmas D, Laborde P, Sautor B, Artigas F (1998) Phytoplankton spring bloom of the Gironde plume waters in the Bay of Biscay: early phosphorus limitation and food-web consequences. Oceanol Acta 21:279-291

> Hutchings JA, Myers RA (1988) Mating success of alternative maturation phenotypes in male Atlantic salmon, Salmo salar. Oecologia 75:169-174
Hutchinson S, Hawkins LE (2004) The relationship between temperature and the size and age of larvae and perimetamorphic stages of Pleuronectes flesus. J Fish Biol 65: 448-459

ICES (2008) Report of the 2nd workshop on age reading of flounder (WKARFLO), 26-29 May 2008, Rostock. ICES CM 2008/ACOM:38

Jager Z (1999) Selective tidal stream transport of flounder larvae (Platichthys flesus L.) in the Dollard (Ems Estuary). Estuar Coast Shelf Sci 49:347-362

Kalish JM (1990) Use of otolith microchemistry to distinguish the progeny of sympatric anadromous and nonanadromous salmonids. Fish Bull 88:657-666

Kerr LA, Secor DH (2012) Partial migration across populations of white perch (Morone americana): a flexible life history strategy in a variable estuarine environment. Estuaries Coasts 35:227-236

Kraus RT, Secor DH (2004) Incorporation of strontium into otoliths of an estuarine fish. J Exp Mar Biol Ecol 302: 85-106

Lassalle G, Rochard E (2009) Impact of 21st century climate change on diadromous fish spread over Europe, North Africa and the Middle East. Glob Change Biol 15: 1072-1089

> Loneragan NR, Bunn SE (1999) River flows and estuarine ecosystems: implications for coastal fisheries from a review and a case study of the Logan River, southeast Queensland. Aust J Ecol 24:431-440

Lundgreen K, Kiilerich P, Tipsmark CK, Madsen SS, Jensen FB (2008) Physiological response in European flounder (Platichthys flesus) to variable salinity and oxygen conditions. J Comp Physiol B 178:909-915

Mangel M, Satterthwaite WH (2008) Combining proximate and ultimate approaches to understand life history variation in salmonids with application to fisheries, conservation and aquaculture. Bull Mar Sci 83:107-130

Marchand J, Tanguy A, Laroche J, Quiniou L, Moraga D (2003) Responses of European flounder Platichthys flesus populations to contamination in different estuaries along the Atlantic coast of France. Mar Ecol Prog Ser 260: 273-284

Martinho F, Dolbeth M, Viegas I, Teixeira CM, Cabral HN, Pardal MA (2009) Environmental effects on the recruitment variability of nursery species. Estuar Coast Shelf Sci 83:460-468

McDowall RM (1997) The evolution of diadromy in fishes (revisited) and its place in plylogenetic analysis. Rev Fish Biol Fish 7:443-462

Miller JA (2011) Effects of water temperature and barium concentration on otolith composition along a salinity gradient: implications for migratory reconstructions. J Exp Mar Biol Ecol 405:42-52

Miller JA, Kent AJR (2009) The determination of maternal run time in juvenile Chinook salmon (Oncorhynchus tshawytscha) based on $\mathrm{Sr} / \mathrm{Ca}$ and ${ }^{87} \mathrm{Sr} /{ }^{86} \mathrm{Sr}$ within otolith cores. Fish Res 95:373-378

Minier C, Levy F, Rabel D, Bocquené G, Godefroy D, Burgeot T, Leboulenger F (2000) Flounder health status in the Seine Bay. A multibiomarker study. Mar Environ Res 50:373-377

> Morais P, Chícharo MA, Chícharo L (2009) Changes in a temperate estuary during the filling of the biggest European dam. Sci Total Environ 407:2245-2259

Morais P, Dias E, Babaluk J, Antunes C (2011) The migration patterns of the European flounder Platichthys flesus (Lin- 
naeus, 1758) (Pleuronectidae, Pisces) at the southern limit of its distribution range: ecological implications and fishery management. J Sea Res 65:235-246

Nicolas D, Lobry J, Lepage M, Sautour B and others (2010) Fish under influence: a macroecological analysis of relations between fish species richness and environmental gradients among European tidal estuaries. Estuar Coast Shelf Sci 86:137-147

> Nissling A, Dahlman G (2010) Fecundity of flounder, Pleuronectes flesus, in the Baltic Sea-reproductive strategies in two sympatric populations. J Sea Res 64:190-198

Nissling A, Westin L, Hjerne O (2002) Reproductive success in relation to salinity for three flatfish species, dab (Limanda limanda), plaice (Pleuronectes platessa), and flounder (Pleuronectes flesus), in the brackish water Baltic Sea. ICES J Mar Sci 59:93-108

> Olsen EM, Heino M, Lilly GR, Morgan MJ, Brattey J, Ernande B, Dieckmann U (2004) Maturation trends indicative of rapid evolution preceded the collapse of northern cod. Nature 428:932-935

Palenzuela J, Iglesias GM, Vilas LG (2004) Pelagic fisheries study using GIS and remote sensing imagery in Galicia (Spain). ICES CM 2004/P:44

Patterson HM, Kingsford MJ, McCulloch MT (2004) The influence of oceanic and lagoonal plume waters on otolith chemistry. Can J Fish Aquat Sci 61:898-904

- Pearce NJG, Perkins WT, Westgate JA, Gorton MP, Jackson SE, Neal CR, Chenery SP (1997) A compilation of new and published major and trace element data for NIST SRM 610 and NIST SRM 612 glass reference materials. Geostand Newsl 21:115-144

Piché J, Hutchings JA, Blanchard W (2008) Genetic variation in threshold reaction norms for alternative reproductive tactics in male Atlantic salmon, Salmo salar. Proc R Soc Lond B Biol Sci 275:1571-1575

Rabiner LR (1989) Tutorial on hidden Markov models and selected applications in speech recognition. Proc IEEE 77:257-286

Radforth I (1940) The food of the grayling (Thymallus thymallus), flounder (Platichthys flesus), roach (Rutilus rutilus) and gudgeon (Gobio fluviatilis) with special reference to the Tweed watershed. J Anim Ecol 9:302-318

Ramos S, Ré P, Bordalo AA (2010) Recruitment of flatfish species to an estuarine nursery habitat (Lima estuary, NW Iberian Peninsula). J Sea Res 64:473-486

Ray GC (2005) Connectivities of estuarine fishes to the coastal realm. Estuar Coast Shelf Sci 64:18-32

Schaffler JJ, Reiss CS, Jones CM (2009) Spatial variation in otolith chemistry of Atlantic croaker larvae in the MidAtlantic Bight. Mar Ecol Prog Ser 382:185-195

Secor DH, Rooker JR (2000) Is otolith strontium a useful scalar of life cycles in estuarine fishes? Fish Res 46: 359-371

Shiao JC, Iizuka Y, Chang CW, Tzeng WN (2003) Disparities in habitat use and migratory behavior between tropical

Editorial responsibility: Nicholas Tolimieri, Seattle, Washington, USA eel Anguilla marmorata and temperate eel A. japonica in four Taiwanese rivers. Mar Ecol Prog Ser 261:233-242

SIE (Système d'Information sur l'Eau) (2011) www. eaufrance.fr (accessed May 2011)

Smedbol RK, McPherson A, Hansen MM, Kenchington E (2002) Myths and moderation in marine 'metapopulations'? Fish Fish 3:20-35

Solemdal P (1967) The effect of salinity on buoyancy, size and development of flounder eggs. Sarsia 29:431-442

> Summers RW (1979) Life cycle and population ecology of the flounder Platichthys flesus (L.) in the Ythan estuary, Scotland. J Nat Hist 13:703-723

- Thériault V, Dunlop ES, Dieckmann U, Bernatchez L, Dodson JJ (2008) The impact of fishing-induced mortality on the evolution of alternative life-history tactics in brook charr. Evol Appl 1:409-423

Thibault I, Dodson JJ, Caron F, Tzeng WN, lizuka Y, Shiao JC (2007) Facultative catadromy in American eels: testing the conditional strategy hypothesis. Mar Ecol Prog Ser 344:219-229

Tsukamoto K, Nakai I, Tesch WV (1998) Do all freshwater eels migrate? Nature 396:635-636

> Tsukamoto K, Aoyama J, Miller MJ (2002) Migration, speciation and the evolution of diadromy in anguillid eels. Can J Fish Aquat Sci 59:1989-1998

Van Achterberg E, Ryan CG, Griffin WL (2001) GLITTER user's manual: on-line interactive data reduction for the LA-ICP-MS Microprobe, Version 4. Acquarie Research, North Ryde

> Volk EC, Blakley A, Schroder SL, Kuehner SM (2000) Otolith chemistry reflects migratory characteristics of Pacific salmonids: using otolith core chemistry to distinguish maternal associations with sea and freshwaters. Fish Res 46:251-266

> Walther BD, Kingsford MJ, O'Callaghan M, McCulloch MC (2010) Interactive effects of ontogeny, food ration and temperature on elemental incorporation in otoliths of a coral reef fish. Environ Biol Fishes 89:441-451

Whitfield AK (1994) Abundance of larval and 0+ juvenile marine fishes in the lower reaches of three southern African estuaries with differing freshwater inputs. Mar Ecol Prog Ser 105:257-267

- Yamashita Y, Otake T, Yamada H (2000) Relative contributions from exposed inshore and estuarine nursery grounds to the recruitment of stone flounder, Platichthys bicoloratus, estimated using otolith $\mathrm{Sr}$ :Ca ratios. Fish Oceanogr 9:316-327

Zhang Z, Runham NW (1992) Initial development of Oreochromis niloticus (Teleostei, Cichlidae) otolith. J Zool 227:465-478

Zimmerman CE, Reeves GH (2000) Population structure of sympatric anadromous and nonanadromous Oncorhynchus mykiss: evidence from spawning surveys and otolith microchemistry. Can J Fish Aquat Sci 57: 2152-2162

Submitted: September 19, 2011; Accepted: June 26, 2012 Proofs received from author(s): September 24, 2012 